\title{
HUBUNGAN KONDISI LINGKUNGAN RUMAH DENGAN KEJADIAN PNEUMONIA PADA BALITA DI WILAYAH KERJA PUSKESMAS TAMAN KABUPATEN SIDOARJO
}

\author{
Carina Delvi Trisiyah ${ }^{1}$, Chatarina Umbul W ${ }^{2}$ \\ ${ }^{1}$ Dinas Kesehatan Kabupaten Sidoarjo, Kabupaten Sidoarjo \\ ${ }^{2}$ Departemen Epidemiologi, Fakultas Kesehatan Masyarakat, Universitas Airlangga \\ Alamat Korespondensi: CarinaDelviTrisiyah \\ E-mail: carindelvi99@gmail.com
}

\begin{abstract}
Pneumonia is the cause of $16 \%$ of underfive children deaths worldwide. The number of cases of pneumonia in Sidoarjo had been continued to increase from 2013-2015. This study aims to describe the condition of home environment with the incidence of pneumonia in underfive children. This research was descriptive observational study with case control study approach. The sample in this study consisted of 32 cases of underfive children who suffering ISPA pneumonia and 32 cases of ARI without pneumonia. The independent variables in this study were occupancy density, ventilation area, floor type, wall type, and cigarette smoke exposure. The results showed that underfive children who suffering ISPA pneumonia have high home density $(68,8 \%)$, often exposed by cigarette smoke (75,0\%), and ventilation respondents was not eligible (100,0\%). Based on the results of this study, the parents should to change the behavior not to smoke in their home. In addition, they should get used to open the door of their house so the air circulation in the house can exchange well.
\end{abstract}

Keywords: underfive children, pneumonia, home environment condition

\begin{abstract}
ABSTRAK
Pneumonia merupakan penyebab dari 16\% kematian balita di seluruh dunia. Jumlah kasus pneumonia di Kabupaten Sidoarjo terus meningkat dari tahun 2013-2015. Penelitian ini bertujuan untuk menggambarkan kondisi lingkungan rumah dengan kejadian pneumonia pada balita. Penelitian ini merupakan penelitian observasional deskriptif dengan pendekatan case control study. Sampel di dalam penelitian ini terdiri dari 32 balita penderita ISPA pneumonia dan 32 kasus ISPA tanpa pneumonia. Variabel bebas dalam penelitian ini adalah kepadatan hunian, luas ventilasi, jenis lantai, jenis dinding, dan paparan asap rokok. Hasil penelitian menunjukkan bahwa balita yang menderita ISPA pneumonia memiliki kepadatan rumah yang tinggi $(68,8 \%)$, balita sering terpapar oleh asap rokok $(75,0 \%)$, dan ventilasi seluruhnya tidak memenuhi syarat $(100,0 \%)$. Berdasarkan hasil penelitian diharapkan kepada orang tua balita yang merokok untuk mengubah perilaku merokok yaitu dengan tidak merokok saat sedang bersama balita dan saat berada di dalam rumah. Selain itu, orang tua harus membiasakan diri membuka pintu rumah agar sirkulasi udara di dalam rumah dapat berjalan dengan baik.
\end{abstract}

Kata kunci: balita, pneumonia, kondisi lingkungan rumah

\section{PENDAHULUAN}

Pneumonia merupakan penyakit yang mengenai jaringan paru-paru (alveoli) dapat disebabkan oleh berbagai mikroorganisme seperti bakteri, virus, dan jamur. Beberapa gejala penyakit pneumonia di antaranya adalah demam, sesak napas, sakit kepala, menggigil, dan batuk yang disertai dengan dahak (Kemenkes RI, 2015).
Pneumonia merupakan penyakit pembunuh utama di dunia karena penyakit ini termasuk ke dalam kategori penyakit yang mematikan. Kasus pneumonia lebih banyak dibandingkan dengan penyakit lain seperti AIDS, campak, dan malaria. Kasus pneumonia di negara berkembang 60\% disebabkan oleh bakteri, sedangkan di negara maju disebabkan oleh virus. Penyakit pneumonia di negara berkembang disebut sebagai pembunuh yang terlupakan (the forgotten disease) (WHO, 2009). 
Angka kematian balita adalah salah satu indikator penting untuk mengukur derajat kesehatan masyarakat. Kematian balita di seluruh dunia pada tahun 2011 adalah 6,9 juta kematian, hampir dua pertiga (64\%) disebabkan karena penyakit menular dengan kondisi seperti pneumonia, diare, malaria, meningitis, tetanus, HIV dan campak (WHO, 2013). Pada tahun 2015, diproyeksikan 5,9 juta anak-anak seluruh dunia akan mati sebelum mencapai ulang tahun kelima mereka. Sebanyak 5,9 juta kematian tersebut, pneumonia bertanggung jawab atas 16\% kematian (IVAC, 2016).

Setiap tahunnya penyakit pneumonia masih menjadi penyakit yang menduduki peringkat 10 besar tertinggi di fasilitas kesehatan. Jumlah kasus pneumonia di Indonesia pada tahun 2016 sebanyak 503.738 kasus dengan jumlah kematian 551 balita. Jumlah kasus ini mengalami penurunan dibandingkan tahun sebelumnya yaitu sebanyak 554.650 kasus pada tahun 2015 (Kemenkes RI, 2016). Penurunan kasus pneumonia tidak selalu menjadi hal yang baik. Minimnya perhatian pemerintah, tenaga kesehatan, dan masyarakat bisa menjadi salah satu penyebab menurunnya penemuan kasus pneumonia.

Pneumonia di Indonesia menyerang segala usia, akan tetapi prevalensi paling tinggi terjadi pada umur 1-4 tahun, sedangkan umur 15- 24 tahun kasus rendah dan meningkat kembali pada usia 45-54 tahun. Hasil Riset Kesehatan Dasar (Riskesdas) tahun 2013 menunjukkan penyebab utama kematian bayi $(0-11$ bulan) akibat penyakit pneumonia sebesar $23,80 \%$ dan penyebab kedua kematian balita (1-4 tahun) akibat pneumonia sebesar $15,50 \%$. Rata-rata setiap harinya balita yang meninggal akibat pneumonia adalah sekitar 83 balita. Berdasarkan data tersebut dapat diketahui penyakit pneumonia berperan terhadap tingginya angka kematian balita di Indonesia, oleh sebab itu penyakit ini masih menjadi masalah kesehatan masyarakat di Indonesia (Riskesdas, 2013).

Penemuan kasus pneumonia pada balita sedini mungkin di pelayanan kesehatan dasar, rujukan dan penatalaksanaan kasus pneumonia merupakan salah satu usaha pemerintah dalam menurunkan angka kematian pneumonia pada balita. Usaha pemerintah tersebut adalah dengan keterpaduan lintas program melalui pendekatan Manajemen Terpadu Balita Sakit (MTBS) di puskesmas. Penyakit pneumonia memiliki ciri-ciri pada saat bernapas terjadi penarikan dinding dada bagian bawah ke dalam disertai dengan peningkatan frekuensi napas (retraksi), suara napas melemah, fremitus melemah, ronki, dan perkusi pekak. Faktor risiko pneumonia dibedakan menjadi faktor instrisik dan faktor ektrinsik. Faktor instrinsik meliputi jenis kelamin, umur, pemberian Air Susu Ibu (ASI), pemberian vitamin A, status gizi, dan status imunisasi. Faktor ekstrinsik meliputi kepadatan hunian dalam satu rumah, luas ventilasi rumah, pencahayaan alami, kelembaban rumah, jenis lantai, jenis dinding, dan paparan asap rokok.

Berdasarkan Keputusan Menteri Kesehatan Republik Indonesia No.829/Menkes/SK/VII/1999, rumah merupakan salah satu kebutuhan pokok manusia yang berfungsi sebagai tempat tinggal atau hunian yang digunakan untuk berlindung dari gangguan iklim dan makhluk lainnya, serta tempat perkembangan kehidupan keluarga. Kondisi fisik rumah dan lingkungan yang tidak memenuhi standar kesehatan merupakan faktor risiko penularan berbagai jenis penyakit, termasuk pneumonia.

Pencemaran lingkungan yang utama berasal dari kegiatan manusia seperti asap rokok. Kebiasaan kepala keluarga yang merokok di dalam rumah dapat berdampak negatif bagi anggota keluarga khususnya balita. Salah satu prioritas masalah dalam indikator Perilaku Hidup Bersih dan Sehat (PHBS) adalah 
perilaku merokok. Merokok merupakan salah satu kebiasaan yang umum ditemukan dalam kehidupan sehari-hari sehingga mudah menemukan orang merokok khususnya lelaki (Bustan, 2007). Indonesia juga merupakan salah satu negara berkembang yang memiliki tingkat konsumsi dan produksi rokok yang tinggi. Sebanyak 62 juta perempuan dan 30 juta laki-laki Indonesia menjadi perokok pasif di Indonesia, dan anak-anak usia 0-4 tahun yang terpapar asap rokok berjumlah 11,4 juta anak (Riskesdas, 2013).

Provinsi Jawa Timur merupakan provinsi yang memiliki kasus pneumonia tertinggi kedua setelah Provinsi Jawa Barat. Jumlah penderita pneumonia di Jawa Timur pada tahun 2015 yaitu 99.190 kasus. Beberapa wilayah/ kota di Jawa Timur yang memiliki kasus terbanyak di antaranya adalah Kabupaten Jember sebanyak 9.066 kasus, Kabupaten Sidoarjo sebanyak 8.834 kasus, Kabupaten Gresik sebanyak 8.536 kasus, dan Kabupaten Bojonegoro sebanyak 8.242 kasus (Dinkes Provinsi Jawa Timur, 2015).

Kasus pneumonia di Kabupaten Sidoarjo dari tahun 2013- 2015 mengalami peningkatan. Berdasarkan hasil laporan di Kabupaten Sidoarjo dari tahun 2013 sejumlah 8.441 kasus, tahun 2014 sejumlah 8.562 kasus dan tahun 2015 menjadi 8.834 kasus. Penemuan kasus pneumonia pada tahun 2015 paling banyak berada di Puskesmas Taman sebesar 945 kasus.

Wilayah kerja Puskesmas Taman merupakan daerah industri dan dekat dengan wilayah Kota Surabaya serta terdapat lebih dari 150 perusahaan besar dan kecil selain industri rumah tangga. Mobilitas penduduk di wilayah kerja Puskesmas Taman cukup tinggi. Mobilitas yang tinggi menyebabkan jumlah penduduk di wilayah Kerja Puskesmas Taman menjadi padat. Hampir $20 \%$ penduduknya adalah penduduk musiman (pekerja yang indekos). Ada berbagai macam penyakit yang berkaitan dengan kondisi lingkungan salah satunya adalah penyakit pneumonia. Tingginya frekuensi kejadian pneumonia pada balita kemungkinan disebabkan oleh kepadatan penduduk. Keadaan penduduk yang padat dapat menciptakan pemukiman yang kumuh (Profil Kesehatan Puskesmas Taman, 2015). Tujuan dari penelitian ini adalah untuk menggambarkan kondisi lingkungan rumah dengan kejadian pneumonia balita di wilayah kerja Puskesmas Taman Kabupaten Sidoarjo.

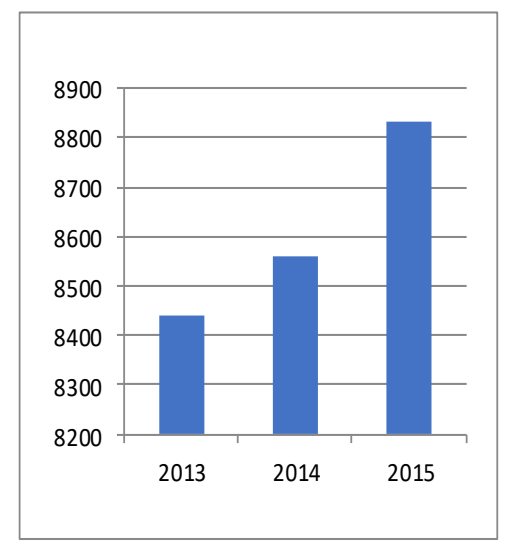

Sumber: Profil Kesehatan Kabupaten Sidoarjo

Gambar 1. Kasus Pneumonia Pada

Balita di Sidoarjo Tahun 2013-2015

\section{METODE PENELITIAN}

Jenis penelitian ini adalah observasional deskriptif. Peneliti hanya bermaksud untuk melakukan observasi tanpa memberikan intervensi pada variabel yang diteliti. Rancang bangun penelitian ini menggunakan desain case control. Desain case control merupakan sebuah studi observasional untuk menilai hubungan antara paparan dan penyakit. Sekelompok orang yang berpenyakit disebut kelompok kasus dan sekelompok orang yang tidak berpenyakit disebut kelompok kontrol. Penelitian ini juga mengikuti perjalanan penyakit ke arah belakang (retrospektif) dimana paparan yang diduga menimbulkan suatu penyakit akan diamati oleh peneliti (Murti, 2003). Variabel yang akan diteliti adalah kondisi lingkungan rumah yang terjadi pada masa lampau sebelum terjadi pneumonia. 
Populasi kasus yaitu semua balita yang datang ke Puskesmas Taman pada periode bulan Agustus 2016- Mei 2017 yang didiagnosis ISPA pneumonia oleh tenaga kesehatan. Populasi kontrol adalah semua balita yang datang ke Puskesmas Taman yang didiagnosis ISPA tanpa pneumonia oleh tenaga kesehatan. Sampel kasus yaitu balita yang datang ke Puskesmas Taman yang didiagnosis ISPA dengan pneumonia oleh tenaga kesehatan. Kriteria inklusi sampel kasus adalah balita yang bertempat tinggal di wilayah kerja Puskesmas Taman, sedangkan kriteria eksklusi adalah terdapat 2 balita dalam satu rumah dan pernah memperbaiki rumah setelah balita diklasifikasi pneumonia seperti mengecat, dan menambah ventilasi. Sampel kontrol adalah balita yang datang ke Puskesmas Taman yang didiagnosis ISPA tanpa pneumonia oleh tenaga kesehatan. Kriteria inklusi sampel kontrol adalah balita yang bertempat tinggal di wilayah kerja Puskesmas Taman, sedangkan kriteria eksklusi adalah terdapat 2 balita dalam satu rumah. Sampel dalam penelitian ini diambil sesuai dengan kriteria sebanyak 64 responden dengan jumlah sampel kasus 32 dan sampel kontrol 32.

$$
\text { Cara pengambilan sampel }
$$

dilakukan dengan menggunakan teknik pengambilan sampel non probability sampling yaitu dengan purposive sampling. Penelitian ini dilakukan di wilayah kerja Puskesmas Taman Kabupaten Sidoarjo.

Penelitian ini terdiri dari 2 variabel, yaitu variabel bebas dan variabel terikat. Variabel bebas adalah kondisi lingkungan rumah meliputi kepadatan hunian, luas ventilasi, jenis lantai, jenis dinding, dan paparan asap rokok. Variabel terikat adalah kejadian pneumonia pada balita. Teknik pengumpulan data dilakukan dengan wawancara dan observasi. Penelitian ini sudah melewati tahap kaji etik.

\section{HASIL}

Kabupaten Sidoarjo pada tahun 2015 mempunyai jumlah penduduk 2.117.279 jiwa tersebar di 18 kecamatan, sebagian besar di wilayah utara yang berbatasan dengan Surabaya dan Sidoarjo bagian tengah. Kabupaten Sidoarjo menjadi daerah utama bagi pencari kerja dan tempat hunian baru mengingat banyak industri di wilayah ini. Jumlah penduduk tertinggi Kabupaten Sidoarjo terdapat di Kecamatan Waru dan Kecamatan Taman. Luas wilayah Puskesmas Taman 19,71 $\mathrm{km}^{2}$, wilayah kerja Puskesmas Taman terbagi menjadi 8 kelurahan, 7 desa yang semuanya sudah swasembada dengan 101 RW dan 448 RT. Jumlah penduduk di wilayah kerja Puskesmas Taman tahun 2015 sebanyak 142.543 jiwa. Jumlah antara penduduk laki-laki dan penduduk perempuan relatif seimbang yaitu 71.607 $(50,23 \%)$ jiwa penduduk laki-laki dan $70.936 \quad(49,76 \%)$ jiwa penduduk perempuan.

Tabel 1. Menunjukkan kelompok yang menderita pneumonia balita banyak terjadi pada umur 25- 59 bulan sebanyak 23 balita $(71,9 \%)$, pada kelompok tidak menderita pneumonia balita banyak terjadi pada umur 2- 24 bulan sebanyak 19 balita (59,4\%). Berdasarkan jenis kelamin sebanyak 32 balita yang menderita pneumonia balita sebagian besar 21 balita $(65,6 \%)$ memiliki jenis kelamin perempuan. Kelompok yang tidak menderita pneumonia memiliki jumlah yang sama antara laki-laki dan perempuan yaitu masing-masing 16 balita $(50,0 \%)$.

Sebanyak 64 ibu balita yang menjadi responden sebanyak 32 balita yang menderita pneumonia sebagian besar 24 balita $(75,0 \%)$ memiliki umur ibu 20-35 tahun. Balita yang tidak menderita pneumonia sebagian besar 27 balita (84,4\%) memiliki ibu yang beurmur 20-35 tahun. Karakteristik ibu balita berdasarkan tingkat pendidikan bervariasi mulai dari SD hingga tamat pergururan tinggi. 
Tabel 1. Distribusi Karakteristik Balita

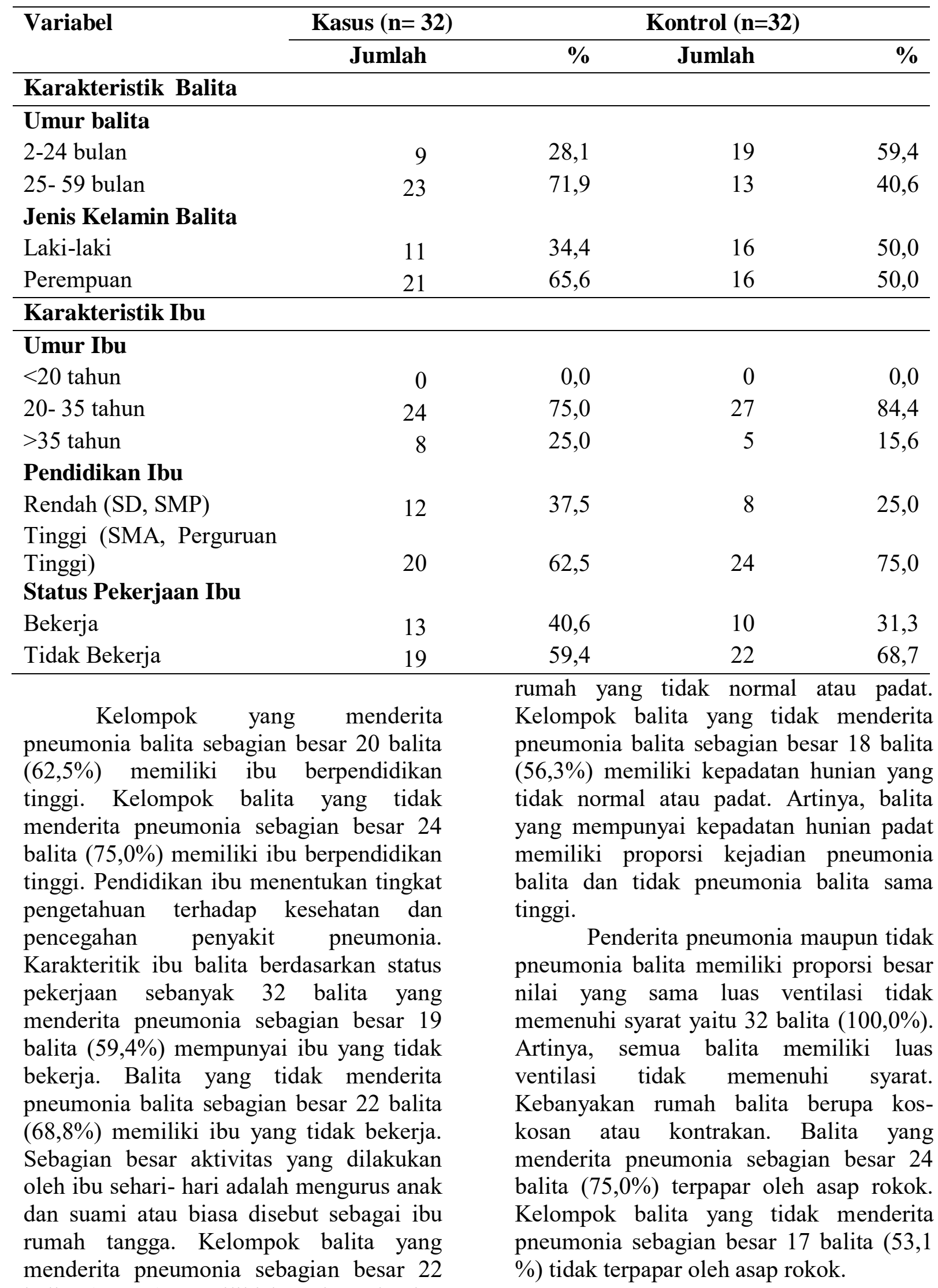
balita $(68,8 \%)$ memiliki kepadatan hunian 
Tabel 2. Analisis Hubungan Antara Kondisi Lingkungan Rumah dengan Kejadian Pneumonia pada Balita

\begin{tabular}{|c|c|c|c|c|c|c|}
\hline \multirow{2}{*}{$\begin{array}{l}\text { Kondisi Lingkungan } \\
\text { Rumah }\end{array}$} & \multicolumn{2}{|c|}{ Kasus $(n=32)$} & \multicolumn{2}{|c|}{ Kontrol $(\mathrm{n}=32)$} & \multirow[b]{2}{*}{$\mathbf{n}$} & \multirow[b]{2}{*}{$\%$} \\
\hline & Jumlah & $\%$ & Jumlah & $\%$ & & \\
\hline \multicolumn{7}{|l|}{ Kepadatan Hunian } \\
\hline Padat & 22 & 68,8 & 18 & 56,3 & 40 & 62,5 \\
\hline Standar & 10 & 31,2 & 14 & 43,7 & 24 & 37,5 \\
\hline \multicolumn{7}{|l|}{ Luas Ventilasi } \\
\hline Tidak memenuhi syarat & 32 & 100,0 & 32 & 100,0 & 64 & 100,0 \\
\hline Memenuhi syarat & 0 & 0,0 & 0 & 0,0 & 0 & 0,0 \\
\hline \multicolumn{7}{|l|}{ Paparan Asap Rokok } \\
\hline Ada & 24 & 75,0 & 15 & 46,9 & 39 & 60,9 \\
\hline Tidak ada & 8 & 25,0 & 17 & 53,1 & 25 & 39,1 \\
\hline \multicolumn{7}{|l|}{ Jenis Lantai } \\
\hline Tidak memenuhi syarat & 5 & 15,6 & 3 & 9,40 & 8 & 12,5 \\
\hline Memenuhi syarat & 27 & 84,4 & 29 & 90,6 & 56 & 87,5 \\
\hline \multicolumn{7}{|l|}{ Jenis Dinding } \\
\hline Tidak memenuhi syarat & 6 & 18,8 & 9 & 28,1 & 15 & 23,4 \\
\hline Memenuhi syarat & 26 & 81,2 & 23 & 71,9 & 49 & 76,6 \\
\hline
\end{tabular}

Kelompok balita yang menderita pneumonia sebagian besar 27 balita $(84,4 \%)$ memiliki jenis lantai yang memenuhi syarat (tegel/keramik). Kelompok balita yang tidak menderita pneumonia sebagian besar 29 balita $(90,6 \%)$ memiliki jenis lantai yang memenuhi syarat (tegel/keramik). Artinya, balita yang memiliki jenis lantai memenuhi syarat memiliki proporsi kejadian pneumonia sama besar dengan balita yang tidak menderita pneumonia.

Kelompok balita yang menderita pneumonia sebagian besar 26 balita $(81,3 \%)$ memiliki jenis dinding memenuhi syarat. Kelompok balita yang tidak menderita pneumonia sebagian besar 23 balita $(68,8 \%)$ memiliki jenis dinding yang memenuhi syarat. Artinya, balita yang memiliki jenis dinding memenuhi syarat memiliki proporsi kejadian pneumonia sama besar dengan balita yang tidak menderita pneumonia.

\section{PEMBAHASAN}

\section{Kepadatan Hunian}

Nilai kepadatan rumah didapatkan dari hasil perhitungan antara luas lantai rumah dengan jumlah anggota keluarga yang tinggal dalam rumah. Hasil penelitian dari 64 rumah balita menunjukkan bahwa sebagian besar rumah memiliki kepadatan rumah yang tinggi. Beberapa rumah balita tersebut berupa kos-kosan atau kontrakan yang dihuni 4-5 anggota keluarga. Jenis tempat tinggal kos-kosan/ kontrakan sangat sempit dan tidak cukup ruang gerak untuk keluarga. Frekuensi kontak dan kedekatan antara satu orang dengan orang lainnya dalam satu rumah juga semakin tinggi, sehingga menyebabkan suhu di dalam rumah terasa panas dan cukup lembab. Selain itu, keberadaan banyak orang dalam suatu rumah akan mempercepat transmisi mikroorganisme bibit penyakit dari seseorang ke orang lain.

Menurut Okoko dkk (2017) kamar yang dihuni lebih dari 2 orang berisiko 1,8 kali menyebabkan kematian balita akibat pneumonia. Hal ini didukung oleh penelitian Wulandari dkk (2016) yang menyatakan bahwa kepadatan hunian rumah berhubungan dengan kejadian pneumonia balita.

Rasio penghuni harus disesuaikan dengan luas rumah, jika luas rumah sempit sedangkan jumlah anggota keluarga banyak akan tidak seimbang. Kondisi 
rumah yang padat memicu tumbuhnya bakteri dan virus penyebab pneumonia yang dapat menular melalui saluran pernapasan. Anak-anak yang masih di bawah umur rentan tertular bakteri dan virus tersebut. Luas lantai rumah yang sehat harus cukup untuk penghuni rumah di dalamnya, artinya agar tidak terjadi kelebihan penghuni dalam rumah maka jumlah penghuni harus disesuaikan dengan luas lantai rumah tersebut (Listyowati, 2013).

Kamar tidur balita minimal memiliki luas $3 \mathrm{~m}^{2}$ / orang dan kamar tidur tidak bertingkat. Selain itu, kamar tidur tidak dihuni lebih dari 2 orang, kecuali untuk suami istri dan anak kurang dari 2 tahun. Hal ini untuk mengendalikan kepadatan hunian dalam rumah, sehingga dapat mengurangi risiko pneumonia pada balita (Soesanto, 2000).

\section{Luas Ventilasi}

Luas ventilasi yang memenuhi syarat menurut Permenkes RI No. 1077/Menkes/Per/V/2011 adalah 10\% dari luas lantai rumah. Hasil ketika di lapangan menunjukkan bahwa seluruh rumah balita yang menjadi responden memiliki luas ventilasi tidak memenuhi syarat. Rata-rata ventilasi kecil dan minim cahaya masuk. Ventilasi tersebut juga jarang di buka dan beberapa rumah ada yang ventilasinya rusak, bahkan ada juga rumah balita yang tidak memiliki ventilasi.

Luas ventilasi rumah yang tidak memenuhi syarat dapat disebabkan oleh tipe rumah yang kecil kerena kepemilikan lahan yang sedikit. Kepemilikan lahan yang sedikit akibat harga lahan di perkotaan yang mahal dan jumlah penduduk yang semakin padat (Trisiyah, 2017).

Menurut Khasanah dkk (2016) luas ventilasi rumah yang tidak memenuhi syarat berisiko 3,6 kali lebih besar terkena pneumonia. Penelitian Hayati dkk (2017) menyatakan hal yang berbeda bahwa tidak ada hubungan yang signifikan antara luas ventilasi rumah dengan kejadian pneumonia pada anak balita.

Lancar atau tidaknya kecepatan ventilasi dalam suatu ruangan ditentukan oleh luas ventilasi. Luas ventilasi yang kurang akan mengakibatkan pergantian udara yang tidak adekuat, sehingga udara menjadi kotor akan mikroorganisme patogen penyebab penyakit respirasi. Ventilasi yang buruk juga berpengaruh terhadap peningkatan kelembapan dalam ruangan yang merupakan media baik untuk tempat hidup mikroorganisme patogen. Ventilasi yang baik akan mengencerkan konsentrasi mikroorganisme patogen dan alergen penyebab penyakit respirasi, sehingga menurunkan penularan penyakit saluran pernapasan salah satunya adalah pneumonia (Kemenkes RI, 2013).

Bakteri Streptococcus pneumoniae merupakan bakteri gram positif, berbentuk bulat telur atau seperti bola dan penghuni normal dari saluran pernapasan bagian atas manusia. Bakteri ini dapat tumbuh dengan baik pada suhu $37,5^{\circ} \mathrm{C}$ dalam media dengan $\mathrm{pH}$ 7,6-7,8 pada suasana aerob dan fakultatif anaerob. Bakteri Streptococcus pneumoniae dapat bertahan selama beberapa hari dalam perbenihan biasa dan dalam sputum kering yang tidak terkena sinar matahari langsung dapat bertahan selama beberapa bulan. Bakteri ini hanya mati oleh sinar matahari langsung (Radji, 2010).

\section{Paparan Asap Rokok}

Berdasarkan hasil pemeriksaan menunjukkan bahwa balita yang menderita ISPA pneumonia sebagian besar memiliki anggota keluarga yang merokok, sedangkan balita yang menderita ISPA tanpa pneumonia sebagian besar tidak memiliki anggota keluarga yang merokok. Keberadaan perokok ini sebagian besar adalah kepala keluarga/ ayah dari balita. Biasanya ayah balita merokok tidak jauh dari balita tersebut. Beberapa di antaranya ayah balita merokok di dalam rumah. Sumber asap rokok di dalam ruangan (indoor) lebih membahayakan daripada di 
luar ruangan (outdoor), karena sebagian besar balita menghabiskan 60-90\% waktunya di dalam ruangan (Kemenkes RI, 2010).

Kejadian pneumonia erat kaitannya dengan paparan asap rokok. Balita yang terpapar asap rokok berisiko 18,480 kali mengalami pneumonia dibandingkan dengan balita yang tidak terpapar asap rokok (Supriyatin, 2015). Hal ini didukung oleh penelitian Wijaya (2014) menyebutkan bahwa kebiasaan merokok anggota keluarga berhubungan dengan kejadian pneumonia balita.

Efek rokok sangat membahayakan bagi kesehatan baik untuk perokok aktif maupun perokok pasif. Perokok pasif juga biasa disebut dengan second hand smoke. Paparan asap rokok pada perokok pasif dapat berupa sidestream smoke yaitu asap rokok samping yang dihasilkan oleh pembakaran rokok itu sendiri, maupun berupa mainstream smoke yang merupakan asap rokok utama yang dihembuskan kembali ke udara oleh perokok aktif. Sidestream smoke memiliki kandungan zat beracun yang lebih berbahaya dibandingkan dengan mainstream smoke. Asap rokok lingkungan atau environmental tobacco smoke merupakan kombinasi dari sidestream smoke dan mainstream smoke. Environmental tobacco smoke terdiri dari sekitar 85\% sidestream smoke dan 15\% mainstream smoke (Pieraccini dkk, 2008).

Asap rokok yang mengandung zatzat residu rokok dapat terhirup langsung oleh orang lain dan dapat tersebar di lingkungan hingga jarak 10 meter. Asap rokok juga dapat menempel di baju maupun benda, seperti gorden, seprai, dan sebagainya yang kemudian dapat dihirup oleh orang lain. Zat-zat residu rokok tersebut biasa disebut dengan third hand smoke. Anak-anak dan balita yang tinggal di rumah dengan perokok aktif menjadi kelompok yang paling berisiko untuk terkena pajanan dari third hand smoke. Zat-zat residu rokok merupakan zat-zat yang berbahaya bagi tubuh apabila terpapar dalam dosis yang tinggi. Beberapa dari zat tersebut merupakan zat karsinogen, yaitu zat yang dapat menyebabkan kanker. Third hand smoke juga dapat mengakibatkan kerusakan organ seperti kerusakan fungsi liver dan jantung, gangguan pernapasan, juga perilaku hiperaktif pada anak yang tinggal di lingkungan third hand smoke. Pneumonia merupakan satu dari sekian banyak penyakit pernapasan yang disebabkan oleh third hand smoke pada anak-anak dan balita (Matt dkk, 2011).

Asap rokok yang dihisap baik pada perokok aktif maupun pasif akan menyebabkan fungsi silia menurun bahkan tidak berfungsi. Jika silia tidak berfungsi, maka tubuh akan memproduksi dahak yang berlebihan. Selain itu, potensi infeksi pada saluran napas sangat besar. Asap rokok juga dapat menyebabkan iritasi, peradangan dan penyempitan saluran napas. Proses penyembuhan bagi penderita pneumonia akan membutuhkan waktu yang lama jika penderita masih terpapar asap rokok karena proses pertahanan tubuh terhadap infeksi tetap akan terganggu (Kusumawati, 2010).

\section{Jenis Lantai}

Hasil pemeriksaan menunjukkan bahwa sebagian besar lantai rumah telah berubin atau memenuhi syarat, namun beberapa rumah kondisi lantai masih terlihat kotor/ jarang dibersihkan. Menurut Kemenkes No. 829/Menkes/SK/VII/1999 tentang persyaratan kesehatan perumahan adalah jenis lantai yang baik harus kedap air dan mudah dibersihkan.

Menurut penelitian Padmonobo dkk (2012) lantai rumah balita yang tidak permanen berisiko 2,635 kali lebih besar menderita pneumonia dibanding dengan balita yang tinggal di rumah dengan lantai yang permanen. Rumah yang sudah berubin memiliki kelembapan yang rendah jika dibandingkan dengan rumah yang lantainya belum berubin. Balita yang sering bermain di lantai yang belum berubin atau lantainya belum memenuhi 
syarat akan mempunyai risiko terkena pneumonia lebih tinggi (Yuwono, 2008).

Jenis lantai tanah akan menyebabkan kondisi dalam rumah berdebu. Keadaan berdebu ini sebagai salah satu bentuk terjadinya polusi udara dalam rumah (indoor air pollution). Debu dalam udara apabila terhisap akan menempel pada saluran napas bagian bawah yang menyebabkan pergerakan silia menjadi lambat, sehingga mekanisme pembersihan saluran pernapasan menjadi terganggu. Jika mekanisme ini terganggu dapat mengakibatkan balita kesulitan bernapas. Oleh karena itu, lantai perlu dilapisi bahan kedap air (disemen, dipasang tegel atau keramik) (Sugihartono $\mathrm{dkk}, 2012$ ).

\section{Jenis Dinding}

Hasil penelitian menunjukkan bahwa sebagian besar kondisi dinding rumah telah memenuhi syarat yaitu terbuat dari bahan yang kedap air, namun ada juga kondisi dinding rumah yang terbuat dari papan/ triplek. Secara teoritis penyebab pneumonia pada balita sangat bervariasi yaitu Streptococcus pneumonia, Haemophilus influenza, Respiratory Syncytial Virus (RSV), Hitoplasma capsulatum, maupun Mycoplasma pneumoniae (WHO, 2006).

Menurut penelitian Yuwono (2008) kondisi dinding rumah balita yang tidak memenuhi syarat mempunyai risiko terkena pneumonia sebesar 2,9 kali lebih besar dibandingkan kondisi rumah balita yang kondisi dinding rumahnya memenuhi syarat. Penelitian lain mengatakan berbeda bahwa balita yang memiliki jenis dinding tidak normal tidak memiliki hubungan dengan kejadian pneumonia (Husnah, 2016).

Dinding yang baik adalah terbuat dari bahan kedap air dan tahan terhadap api serta tidak terbuat dari bahan yang mudah melepaskan zat-zat yang dapat membahayakan kesehatan seperti tembok dan keramik. Dinding yang tidak baik adalah terbuat dari kayu/ bambu dan mudah terbakar. Kondisi dinding rumah yang tidak dilengkapi dengan luas ventilasi dapat memberikan kontribusi terciptanya kelembapan yang tidak normal di dalam rumah. Kelembapan rumah yang tidak normal akan menjadi pra kondisi pertumbuhan bakteri maupun virus penyebab pneumonia. (Padmonobo dkk, 2012).

\section{SIMPULAN}

Terdapat lima variabel dalam penelitian ini. Sebagian besar balita memiliki kepadatan hunian rumah yang padat serta balita sering terpapar asap rokok di dalam rumah. Luas ventilasi dari seluruh responden adalah tidak memenuhi syarat.

Saran yang dapat diberikan yaitu bagi orang tua balita yang merokok agar mengubah perilaku merokok yaitu dengan tidak merokok saat sedang bersama balita dan saat berada di dalam rumah. Selain itu, orang tua harus membiasakan diri membuka pintu rumah agar sirkulasi udara di dalam rumah dapat berjalan dengan baik.

\section{DAFTAR PUSTAKA}

Bustan, M. 2007. Epidemologi Penyakit Menular. Yogyakarta: Rineka Cipta.

Departemen Kesehatan RI tahun 1999. Kepmenkes RI No.829/Menkes/SK/VII/1999.

Persyaratan Kesehatan Perumahan. Jakarta: Depkes RI

Dinas Kesehatan Kabupaten Sidoarjo tahun 2013. Data Profil Kesehatan Kabupaten Sidoarjo tahun 2013. Sidoarjo: Dinas Kesehatan Kabupaten Sidoarjo.

Dinas Kesehatan Kabupaten Sidoarjo tahun 2014. Data Profil Kesehatan Kabupaten Sidoarjo tahun 2014. Sidoarjo: Dinas Kesehatan Kabupaten Sidoarjo. 
Dinas Kesehatan Kabupaten Sidoarjo tahun 2015. Data Profil Kesehatan Kabupaten Sidoarjo tahun 2015. Sidoarjo: Dinas Kesehatan Kabupaten Sidoarjo.

Dinas Kesehatan Kabupaten Sidoarjo tahun 2015. Data Profil Kesehatan Puskesmas Taman tahun 2015. Sidoarjo: Dinas Kesehatan Kabupaten Sidoarjo.

Dinas Kesehatan Provinsi Jawa Timur tahun 2015. Data Profil Kesehatan Provinsi Jawa Timur tahun 2015. Surabaya: Dinas Kesehatan Provinsi Jawa Timur.

Hayati A. M., Suhartono, Sri W. 2017. Hubungan Antara Faktor Lingkungan Fisik Rumah dengan Kejadian Pneumonia pada Anak Balita di Wilayah Kerja Puskesmas Semin I Kabupaten Gunung Kidul. Jurnal Kesehatan Masyarakat [ejournal] 5(5).

Husnah, 2016. Kondisi Lingkungan Rumah Sebagai Faktor Risiko Kejadian Pneumonia Balita. Skripsi. Surabaya: Universitas Airlangga.

International Vaccine Access Center (IVAC). 2016. Pneumonia \& Diarrhea Progress Report: Reaching Goals Through Action and Innovation. IVAC.

Kementrian Kesehatan Republik Indonesia tahun 2010. Pneumonia Balita. Buletin Jendela Epidemiologi, Volume 3. Jakarta: Kementrian Kesehatan RI.

Kementrian Kesehatan Republik Indonesia tahun 2013. Profil Kesehatan Indonesia 2013. Jakarta: Kementrian Kesehatan RI.

Kementrian Kesehatan Republik Indonesia tahun 2015. Profil Kesehatan Indonesia $2015 . \quad$ Jakarta: Kementrian Kesehatan RI.

Kementrian Kesehatan Republik Indonesia tahun 2016. Profil Kesehatan Indonesia 2016. Jakarta: Kementrian Kesehatan RI.
Khasanah M., Suhartono, Dharminto. 2016. Hubungan Kondisi Lingkungan dalam Rumah dengan Kejadian Pneumonia Pada Balita di Wilayah Kerja Puskesmas Puring Kabupaten Kebumen. Jurnal Kesehatan Masyarakat [e-journal] 4(5).

Kusumawati, Ita, 2010. Hubungan Antara Status Merokok Anggota Keluarga dengan Lama Pengobatan ISPA Balita di Kecamatan Jenawi. Thesis. Surakarta: Universitas Sebelas Maret.

Listyowati, 2013. Hubungan Kondisi Lingkungan Fisik Rumah Dengan Kejadian Pneumonia pada Balita di Wilayah Kerja Puskesmas Tegal Barat Kota Tegal. Jurnal Kesehatan Masyarakat [e-journal] 2(1).

Matt, G., Quintana, P., Destaillats, H., Gundel, L., Sleiman, M., Singer, B., Jacob, P., Benowitz, N., Winickoff, J., Rehan, V., Talbot, P., Schick, S., Samet, J., Wang, Y., Hang, B., Martins-Green, M., Pankow, J. and Hovell, M. 2011. Thirdhand Tobacco Smoke: Emerging Evidence and Arguments for a Multidisciplinary Research Agenda. Environ Health Perspect [e-journal] 119(9).

Murti, Bhisma. 2003. Prinsip dan Metode Riset Epidemiologi. Yogyakarta: Gadjah Mada University Press.

Okoko A.R., Hossie E., N'djoboMamadoud I.C., Moyen E., Ekouya Bowasa G., Moyen G. 2017. Pneumonia of Children under 5 Years of Age in Brazzaville (Republic of Congo). Open Journal of Pediatrics [e-journal].

Padmonobo, H., Setiani o., Joko T. 2012. Hubungan Faktor-Faktor Lingkungan Fisik Rumah dengan Kejadian Pneumonia ada Balita di Wilayah Kerja Puskesmas Jatibarang Kabupaten Brebes. 
Jurnal Kesehatan Lingkungan Indonesia. [e-journal] 11(2).

Peraturan Menteri Kesehatan Republik Indonesia tahun 2011. Keputusan Menteri Kesehatan Republik Indonesia Nomor 1077/Menkes/Per/V/2011 tentang Penyehatan Udara dalam Ruang Rumah. Jakarta.

Pieraccini, G., Furlanetto, S., Orlandini, S., Bartolucci, G., Gramini, L., Pinzauti, S., \& Moneti, G. 2008. Identification And Determination Of Mainstream And Side Stream Smoke Components In Different Brands And Types Of Cigarettes By Means Of Solid- Phase Microextraction- Gas Chromatography- Mass Spectometry. Journal of Chromatography [e-journal] 1180(1).

Radji M. 2010. Buku Ajar Mikrobiologi Panduan Mahasiswa Farmasi dan Kedokteran. Jakarta: EGC.

Riset Kesehatan Dasar tahun 2013. Jakarta: Balitbang Kemenkes RI.

Soesanto, S.S., Lubis, A. 2000. Hubungan Kondisi Perumahan dengan Penularan Penyakit ISPA dan TB Paru. Media Litbang Kesehatan [ejournal] 10(2).

Sugihartono S, Rahmatullah P, Nurjazuli N. 2012. Analisis Faktor Risiko Kejadian Pneumonia Pada Balita Di Wilayah Kerja Puskesmas Sidorejo Kota Pagar Alam. Jurnal Kesehatan Lingkungan Indonesia [e-journal] 11(1).

Supriyatin, O., Sulistyaningsih. 2015. Hubungan Paparan Asap Rokok
Dan Rumah Tidak Sehat dengan Kejadian Pneumonia pada Anak Balita di Puskesmas Wirobrajan Yogyakarta Tahun 2015. Skripsi. Yogyakarta: STIKES Aisyiyah.

Trisiyah, C. D., 2017. Hubungan Pola Menyusui dan Kondisi Lingkungan Rumah dengan Kejadian Pneumonia pada Balita di Wilayah Kerja Puskesmas Taman Kabupaten Sidoarjo. Skripsi. Surabaya: Universitas Airlangga.

WHO. 2006. Pneumonia the Forgotten Killer of Children.WHO.

WHO. 2009. Global Action Plan for the Prevention and Control of Pneumonia (GGAP). WHO.

WHO. 2013. Ending Preventable Child Deaths from Pneumonia and Diarrhoea by 2025. WHO.

Wijaya, Bahar, H., 2014. Hubungan Kebiasaan Merokok, Imunisasi dengan Kejadian Penyakit Pneumonia pada Balita di Puskesmas Pabuaran Tumpeng Kota Tangerang. Forum Ilmiah [ejournal] 11(3).

Wulandari, P.S., Suhartono, Dharminto, 2016. Hubungan Lingkungan Fisik Rumah dengan Kejadian Pneumonia pada Balita di Wilayah Kerja Puskesmas Jatisampurna Kota Bekasi. Jurnal Kesehatan Masyarakat [e-journal] 4(5).

Yuwono, T.A., 2008. Faktor-Faktor Lingkungan Fisik Rumah yang Berhubungan dengan Kejadian Pneumonia pada Balita di Wilayah Kerja Puskesmas Kawungaten Kabupaten Cilacap. Thesis. Semarang: Universitas Diponegoro. 